\title{
The Productive Approach to the Problem of Facilitative Interaction and the Development of the Person's Creativity
}

\section{Продуктивний підхід до проблеми фасилітативної інтеракції та розвитку творчості особистості}

\section{Oleksandr Nabochuk}

Ph. D. in Psychology, Head Adviser of Rivne Regional Council, Rivne (Ukraine)

ORCID ID: https://orcid.org/0000-0002-1448-7687

Researcher ID: http://www.researcherid.com/rid/AAE-4773-2021

E-mail: nab_ol@ukr.net

\section{Олександр Набочук}

Кандидат психологічних наук, радник голови Рівненської обласної ради, м. Рівне (Україна)

\section{ABSTRACT}

The aim of our research is: to show the context of the productive approach to the problem of facilitative interaction and the development of the person's creativity in this connection.

The following theoretical methods of the research were used to solve the tasks formulated in the article: the categorical method, structural and functional methods, the methods of the analysis, systematization, modeling, generalization.

The results of the research. Theoretical analysis of psychological researches on this issue allows us to identify several basic approaches to the study of creativity in Foreign Psychology: 1) psychodynamic approach, which describes

Address for correspondence, e-mail: kpnu_lab_ps@ukr.net Copyright: (C) Nabochuk Oleksandr

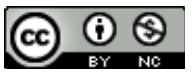

(C) Nabochuk Oleksandr

DOI (article): https://doi.org/10.32626/2227-6246.2021-51.165-189 
creativity through the interaction of «It», "Me», "Super-Me»; 2) behavioral approach, which considers creativity as a result of behavior with strict adherence to the scheme "stimulus - reaction»; 3) pragmatic approach, which emphasizes the possibilities of practical use of a creative product and, as a result, the allocation of other resources for the creative use of this product; 4) psychopathological approach, which considers creativity as a by-product of mental disorders of the person; 5) productive approach, which evaluates creativity in a view of the novelty of a final product; 6) procedural approach, which considers creativity as a process; 7) humanistic approach, which emphasizes the actual self-expression of the creator.

It was proved that creativity is a source product of creative activity. This approach calls creative not only masterpieces of world, such as culture and art, inventions of technologies, new concepts in science, but also pieces of original interior design, unusual clothing design, etc. A wide range of creative products should actualize person's abilities to differentiate according to the levels of individual creativity. Thus, the representatives of the productive approach for the first time argue about a natural level of creative activity.

Conclusions. Thus, we conclude that facilitative interaction is characterized by the following suggestions. Firstly, creative activity is seen as a person's need to adapt to new conditions of the reality. It is the ability of the person to include something new into the process of his / her life, to adapt to external conditions of the activity, which, as a rule, promotes greater flexibility of the subject in solving problems and situations, increases the possibility of personal improvement and growth. Creative activity is seen as the process of inventing a product that did not yet exist for a given person (although this product may already exist in principles). The characteristics of these new products or processes are their novelty, originality, expediency, validity, the ability to meet their own needs, adequacy.

Productive approach to study of the development of creativity in the process of facilitative interaction shows that this approach to some extent reduces a person's creative ability to manifest his / her individual characteristics. The productive approach offers a very original and balanced understanding of the creativity, which is based on the universality of the creativity, its accessibility for everyone, the role of creativity not only as a way to adapt to external environmental conditions, but also as a tool for qualitative change.

Key words: productive approach, facilitative interaction, the person's creativity, the universality of the creativity, the accessibility of the creativity for everyone, to adapt to external environmental conditions.

(C) Nabochuk Oleksandr

DOI (article): https://doi.org/10.32626/2227-6246.2021-51.165-189 


\section{Introduction}

The study of the problem of creativity nowadays becomes complex, it is the subject of the analysis of various social disciplines, and it is the important area of different psychological, sociological and psycholinguistic researches, which are influenced by other areas of knowledge about a Man - Philosophy, Sociology and Psychology. Defining the essence of creativity and the formation of creative potential of a teacher is one of the most actual issues for the Psychology of the Personality and its development.

Theoretical analysis of psychological researches on this issue allows us to identify several basic approaches to the study of creativity in Foreign Psychology:

1. Psychodynamic approach, which describes creativity through the interaction of «It», «Me», «Super-Me» (Amabile, 1983; Enkvist, 1990; Ludwig, 1992).

2. Behavioral approach, which considers creativity as a result of behavior with strict adherence to the scheme «stimulus - reaction» (Bolle, 2014; Flossdorf, 1981).

3. Pragmatic approach, which emphasizes the possibilities of practical use of a creative product and, as a result, the allocation of other resources for the creative use of this product (Boden, 1991; Ekvall \& Britz, 2001).

4. Psychopathological approach, which considers creativity as a by-product of mental disorders of the person (Collins \& Amabile, 1999; Gehrmann, 2015).

5. Productive approach, which evaluates creativity in a view of the novelty of a final product (Гончарук \& Онуфрієва, 2018; Jamison, 1995; Mykhalchuk \& Kryshevych, 2019).

6. Procedural approach, which considers creativity as a process (Kraus, 2015; Renzulli, 1991; Zubiashvily, Kocharian, Lunov, Barinova \& Onufriieva, 2020).

7. Humanistic approach, which emphasizes the actual self-expression of the creator (Mykhalchuk \& Ivashkevych, 2018).

(C) Nabochuk Oleksandr

DOI (article): https://doi.org/10.32626/2227-6246.2021-51.165-189 
The representatives of the productive approach (Гончарук \& Онуфрієва, 2018; Jamison, 1995; Mykhalchuk \& Kryshevych, 2019) emphasize that creativity is a source product of creative activity. These scientists call creative not only masterpieces of world, such as culture and art, inventions of technologies, new concepts in science, but also pieces of original interior design, unusual clothing design, etc. A wide range of creative products should actualize person's abilities to differentiate according to the levels of individual creativity. Thus, the representatives of the productive approach for the first time argue about a natural level of creative activity (Amabile, Conti, Lazenby \& Herron, 1996).

Thus, M. Boden (1991) in his researches identifies two levels of creativity, which were defined by the researcher as Self-creativity (or historical creativity) and IP-creativity (individual personal creativity). According to this concept, a human-generated idea is IP-creative if it is completely new to himself / herself, no matter how many times other individuals have already generated this idea; on the contrary, Self-creative is the idea that has never arisen in the entire history of mankind.

The researchers also emphasize that fact that the model of a creative activity will be incomplete without taking into account the significance of the creative product both for the individual and for his / her social environment (Mykhalchuk \& Kryshevych, 2019). However, the issue of creative product criteria remains controversial for proponents of a productive approach. For example, G. Ekvall (1997) believes that the creative product must be distinguished by some originality, and it must be needed by the social environment in general.

In such a way the aim of our research is: to show the context of the productive approach to the problem of facilitative interaction and the development of the person's creativity in this connection. 


\section{Methods of the research}

The following theoretical methods of the research were used to solve the tasks formulated in the article: a categorical method, structural and functional methods, the methods of the analysis, systematization, modeling, generalization.

\section{Results and their discussion}

At foreign language classes the form of studying and control the results is a dialogue that takes place at all stages of the learning activity and to which pupils would involve the teacher, inducing reasoning, summarizing and concluding, expressing opinions and evaluating. Learning dialogical speech in the practice of teaching foreign languages is often reduced to developing the ability to exchange short replicas (exclamations, elliptical sentences).

Dialogical speech can be classified, based on the number of participants of communication, their social and communicative characteristics, the ratio of the language motives of the partners, the size of the dialogical text, the volume and the structure of individual statements, the psychological nature, which underlies the content of the statements and their other characteristics. The teacher has to pay a great attention to the number of participants in dialogue communication. Dialogue can take place between two, three and much more partners of communication. To indicate the dialogue that is held between two partners, the teacher'll accept the term of a dialogue. A trilogue is between three partners, when there are more than three people it is a polylogue.

In this article we will mainly consider dialogical contacts of two persons. The communicative structure of dialogical speech is the simplest one. It is realized within the limits of individual communication, which is usually inherent in confidential, intimacy situations. However, individual communication can also have an official character, which requires the participants

(C) Nabochuk Oleksandr

DOI (article): https://doi.org/10.32626/2227-6246.2021-51.165-189 
DOI: https://doi.org/10.32626/2227-6246.2021-51 2021. випуск 51

of the task manager to perform certain etiquette, officially business style of speech.

The dialogue can be individual, between two or more persons, but the conversation of two people can take place in the presence of the third person (for example, a teacher) or the third pupil.

Educational dialogue should be considered a frontal conversation of the teacher with a group of pupils, when he / she consistently introduces the communicative activities of one pupil to another person, while the latter does not communicate with each other, does not respond to the replica of their colleagues. Psychological task consists of the fact that such polydialogical contact of the teacher with a group of pupils became a group conversation. In such a way a polylogue is characterized by multi-directional character. A special place in the system of oral communication is a theatrical dialogue, when the participant has the audience in the whole.

Let us show the social and communicative nature of dialogical communication. There are three varieties of dialogical speech: a social contact, a business conversation and a free conversation.

A social contact is the most common in the social sphere of communication (buying a newspaper in a shop or an airline ticket in the air-flight) and it is preceded in the form of a «jogging» dialogue with a relatively rapid change of the roles of the speaker and the listener.

For example:

S.1. To me and Nataliia ten postcards, this are these.

S.2. Fourteen hryvnias, please.

S.1. Please.

A business conversation is observed in the spheres of oral communication: professional, social, everyday life and the sphere of education.

A free conversation is not limited to a circle of persons, nor at times, and it becomes a form of interpersonal, informal (c) Nabochuk Oleksandr

DOI (article): https://doi.org/10.32626/2227-6246.2021-51.165-189 
communication, the purpose of which is the speech activity itself. Example:

S.1. Yesterday we and Helen went to the country house.

S.2. And I did not go out of the house: there was a lot of work.

S.1. Listen, and where is Deville? I have not seen him for a long time.

S.2. He is in town. I met him at a book exhibition.

S.1. By the way, is it still open, the exhibition, I mean? I was not on it, I wonder?

Let's analyze the ratio of linguistic motives of partners in a dialogue. From this point of view we can distinguish: there is so called balanced dialogue, a dialogue-questioning (the afferent dialogue), a dialogue-discussion, a dialogue-disagreement. In the balanced «quiet» dialogue plays the role of the initiator of the conversation when it is not well seen, there is a conversation of equal partners.

In the afferent dialogue the role of partners is sufficiently fixed: one partner asks, the other one responds (an interview, the exam, the interview with a patient, an investigator and a witness). For example:

S.1. What hours did you pass past the Semaphore carriage?

S.2. Somewhere around 11 o'clock in the evening.

S.1. Have you seen a one-room mansion with a green gateway to the car?

S.2. Yes, I saw.

S.1. Could you recall the brand and color of the car?

Pupils usually respond to replicas with the help of other suggestions, at the level of the corresponding passive speech. The teacher should pay the particular attention to the development of pupils' ability to start a dialogue. In the practice of teaching dialogical speech it was not given the necessary attention to the formation of a culture of actualization of the inner world of pupils with the aim of issuing speech acts which are initially active.

(C) Nabochuk Oleksandr

DOI (article): https://doi.org/10.32626/2227-6246.2021-51.165-189 
DOI: https://doi.org/10.32626/2227-6246.2021-51 2021. випУСК 51

When the partners adhere to different points of view according to the same problem, then there is a debate, a dispute. At the same time the motives of the communicants are identical: each of them tries to prove his / her own point of view, insists on his / her own mind. For example:
S.1. You did!
S.1. You did! You did!
S.2. I didn't!
S.2. No, I didn't!
S.1. You did!
S.1. Ouch! You hit me!
S.2. I didn't!
S.2. I did!

A dialogue of incomprehension can be caused by various reasons. It's a reluctance to listen, and misunderstandings between the partners, and just bad listening to the partners. Example:

S.1. Where are you going?

S.2. Pardon?

S.1. I asked you where were you going?

S.2. I'm going to the stationer's.

S.1. To the station? Are you going away?

S.2. I said I was going to the stationer's. I have to buy some envelopes. I want to write some letters today.

S.1. I beg your pardon?

S.2. I said I wanted to write some letters.

S.1. Do you want to write a letter at the station?

S.2. No! At home.

S.1. But you said you were going to the station.

S.2. No, to the STATIONER'S!

S.1. Ah, the stationer's! Why didn't you say so at once?

The partners have to ensure that the speech acts of each of the participants in the dialogue cover as many different types of expression as it is possible. The dialogue is usually characterized by short replicas. If a pupil actively participates in a dialogue, successfully selects replicas, that is his / her speech it is communicatively meaningful, then the teacher should be put into the example of such a pupil.

(C) Nabochuk Oleksandr

DOI (article): https://doi.org/10.32626/2227-6246.2021-51.165-189 
Let us show such stages as the readiness of speech in the process of dialogical communication. In real conditions communication is prepared, thought over before dialogical speech is relatively rare, mainly in situations of administrative sphere legal, professional communication, in the field of social activity. Prepared dialogue is inherent in the field of education, it often has the appearance of a monologue that has not been realized (for example, the teacher, making sure that the pupil can not present the material, tries to ask questions, that is, through a dialogue, to look at the creative information, get the correct answers). If one of the partners can think of his / her verbally meaningful party in the conversation, then the whole dialogue is impossible: it is difficult to reliably predict the reaction of the partner, all the sides of this or that topic.

Thus, from the methodological point of view dialogical communication (statements of each partner) should be divided into prepared and unprepared. The unprepared dialogical communication may be home-done and spontaneous. The latter is characterized by an unpreparedness of the speech act and is carried out by itself, without control from the side of teacher's perception. The teacher should encourage pupils to develop both prepared and unprepared dialogical speech to form their creative potential.

Also, the productive creative approach in Psychology the teacher has to use at the lessons the ways of organizing facilitative interaction. Facilitative interaction at the English lessons is also possible when the teacher organizes the heuristic conversation. The teacher should be understood as the theory of teaching methods of foreign languages, that is, the set of methods of studying and learning by means of guidance questions.

For the pupil the same word «heuristics» is understood as the art of finding truth in the ideal sense, which has to master the joyness, the satisfaction of the emergence of a successful thoughts or a desire to discover something. The dominant way

(c) Nabochuk Oleksandr

DOI (article): https://doi.org/10.32626/2227-6246.2021-51.165-189 
of realizing this method can be the conversation itself and the educational debate in general.

The purpose of the heuristic conversation is the development of pupils' creative thinking. For the in-depth understanding of the content of artistic text it is expedient to conduct $a$ heuristic conversation, which can be divided into three stages:

1. Pre-emptive questions, which have the aim of revealing the degree of general perception of the text.

2. Questions about the poetics context of the novel.

3. Common questions for understanding the ideological and artistic content of the text.

The effectiveness of the method of heuristic conversation depends on two main conditions: pupils' readiness; thought by the teacher of a clear system of questions. Applying the heuristic method (in such a way the teacher largely prepares pupils for creative analytical activity).

It should be noted that any conversation (reproducing, systematizing, heuristic) is a dialogical method of teaching in which the teacher with the help of well-posed questions urges pupils to reproduce previously acquired knowledge, make independent conclusions - so called generalizations based on the acquired actual material.

The conversation may start the discussion. This technique is divided into some stages: 1) preparatory stage; 2) stage of conducting; 3 ) stage of conclusions.

One of the natural ways to achieve the development of facilitative interaction and interference is the discussion (the higher level of the heuristic conversation), that is the discussion according to a particular problem through the exchange of thoughts in coincidence or dissenting of ideas. The discussion as a practice in speech involves the development of skills in a clear, logical way to formulate pupils' thoughts, namely to help them to be able to make generalizations on the basis of examples, to conduct analogies, to evaluate priorities, to give reasons, etc., and the ability to conduct a discussion, that is to (c) Nabochuk Oleksandr

DOI (article): https://doi.org/10.32626/2227-6246.2021-51.165-189 
be able to listen without interrupting, to express relevant and clear information.

The main feature of the discussion is the attractiveness of the subject of this discussion, clearly defined and interesting for the participants in the process of communication. Interesting does not necessarily mean controversial, and the discussion is not just a «dispute». In a real communication, as a rule, we discuss the usual, interesting things for us, and only some of them are really controversial.

Proposing a subject for the discussion, the teacher should not provide pupils with all the information necessary for the discussion, so as not to deprive them of their initiatives. $\mathrm{Pu}$ pils must independently put forward convincing evidence, bring new facts, examples into discussion, and not paraphrase ready-made ideas.

The success of the discussion depends, firstly, on the number of pupils who participate in the discussion, and secondly, how motivated there are their speech actions. If the attention of the participants is focused on someone who speaks, if they are interested, react to humor, etc., the motivation of speech activity is rather high. Consequently, absolute participation and high motivation are the factors that indicate the effectiveness of the discussion.

An optimally active discussion is a talk in which all the pupils of the group participate, can not be carried out when working with the whole group, that is when conducting the discusses material in a centralized manner. Decentralization and grouping of pupils into groups / couples makes it possible to avoid this organizational disadvantage. The main thing here is to guarantee the heterogeneity or homogeneity of the groups so that there are no serious conflicting relationships between the pupils. It is desirable that the composition of each group be permanent, this will help to eliminate stress and problems with this discipline.

(c) Nabochuk Oleksandr

DOI (article): https://doi.org/10.32626/2227-6246.2021-51.165-189 
When working in groups, the time of active participation of each pupil in the discussion increases. At the same time, the state of anxiety for shy schoolchildren is reduced, which helps them to overcome the fear of mistakes.

Also the physical aspect of group activity is important: the participants in the discussion are at a close distance, face to face, and turn to each other directly, especially, using the necessary auxiliary material. In addition, group work opens teachers' opportunities for mutual learning: pupils correct each other, help pick up means of expressing thoughts. When working in groups, the role of a teacher greatly changes. From the instructor, the controller, the corrector if it is necessary turns into an organizer, assistant or a partner.

Group discussion can take place as a role-playing game. In the role organization of the discussion the group is divided into small groups - micro-groups - or pairs of pupils, which are offered closely to real psychological situations and roles for playing. The role-playing game reveals great opportunities for communicative practice. Reincarnation in different ways allows pupils to express the most diverse communicative intentions and mood according to a real purpose of communication.

The right choice of subject matter is equally important. Pupils' interest in problems can cause materials that are as close as it is possible to their livelier orientations, while an unusual, exotic topic of discussion can stimulate a more lively response of participants.

Discussions are preceded by preparatory work. Pupils report a problem for the discussion, after which it is advisable to carry out a brainstorming exercise in which pupils express their ideas about the problem and note them to use in the discussion. The teacher then proposes assignments between groups, assigns, leads, distributes auxiliary materials. Here it is timely to remind pupils of the rules of a discussion: a balanced participation of all group members, respect for the leader, a ban on interrupting the speaker.

(C) Nabochuk Oleksandr

DOI (article): https://doi.org/10.32626/2227-6246.2021-51.165-189 
Encouraging participation in the discussion is one of the problems during the discussion. To include all pupils the teacher can distribute separate questions, problems between the members of the group. Thus, the final solution to the problem is achieved by combining the versions.

The end of the group discussion is not the end of the discussion according to the problem. The activity of pupils should be appreciated by the teacher and the whole group. Feedback can be made in different ways: summing up the discussion by a representative from each micro-group in front of the group, comparing the conclusions of different micro-groups, comparing proposals and combining them into a general version of the group, or just repeating the discussion of one of the microgroups in front of the whole group.

The discussion can be completed both by a teacher and pupils. In addition, not all issues can be resolved. The discussion will have an open outcome and can be continued at any time, in another place and with the presence of other persons.

The discussion may be based on the material of the text having been read. To achieve facilitative interaction at the English lessons it is advisable to organize the activity in three stages:

I. Conditional-managed interaction (group work, $10 \mathrm{~min}$. ). At this stage the expressions of pupils are largely confined to the text. After individual reading of the text pupils firstly discuss in the groups its title, and then each one in turn passes in one foreign language according to one of the events described in the text, using, for example, such a table:

\begin{tabular}{|c|c|c|c|c|}
\hline Place & Approximate & Time & Event & Significance \\
\hline
\end{tabular}

When one pupil says, the rest of children interact with him / her, helping him / her to pick up the linguistic means, reminiscent of certain details of the content of the text, so that communication can continue. Pupils work in groups of 4 participants, one of whom is the leader of the discussion.

(C) Nabochuk Oleksandr

DOI (article): https://doi.org/10.32626/2227-6246.2021-51.165-189 
DOI: https://doi.org/10.32626/2227-6246.2021-51

2021. випУСК 51

A task for a group: Form groups of four. Each group has 10 minutes; at first, discuss the meaning of the title and try to reach the group agreement; for the second, retell one milestone according to the text.

2. Managed interaction (paired work, 5 min.). Pupils work with a set of drawings that illustrate story lines or certain important events described in it. Each pupil describes his / her drawing without showing his / her partner. The partner summarizes the message and gives the title for a picture. The pupils' statements support the questions that are written on the board.

Who are the characters?

What are they doing there?

What is the setting?

At what date does it take place?

How do the characters feel about themselves?

This stage is optional.

A task for a group: Select a partner to form a pair. Take turns and use 5 minutes each to describe your «secret picture» to your partner. The partner should summarize the significance of the picture and then give a title. Use the list on the blackboard as a reference for the description.

3. Free interaction (work in pairs, 10 min.). During the previous activity, pupils got a complete picture of both the subject of the discussion and the means of expressing their thoughts. They are ready for free communication with a partner: to discuss their own life experiences, certain events from the experience of other people whose roles they perform, or before conducting a survey, a questioning, the interviewing, acting as a journalist, a columnist, a writer, etc.

A task for a group: Each pair should take 10 minutes for a free conversation about some significant events for your partner can be:

A: two friends recalling your schooldays;

(C) Nabochuk Oleksandr

DOI (article): https://doi.org/10.32626/2227-6246.2021-51.165-189 
DOI: https://doi.org/10.32626/2227-6246.2021-51

2021. випуск 51

B: a journalist and a well-known writer talking about a memorable event;

C: a social surveyor and his / her informant in a questionnaire.

Our teaching practice at school № 12 in Rivne, makes it possible the natural transition from precommunicative to communicative speech activity, arguing the appropriate positive mood in the class, which is a necessary factor in reducing the level of affective filter - the negative emotional state of pupils.

The given examples of exercises testify that the best opportunities for practice in the process of free communication in a foreign language are created, provided that there is an interesting subject of the discussion and its organization as a group role-playing game. In this case, the discussion is a model of the natural process of communication.

Next, we will offer some variations of discussion-based exercises, which can be used by the teacher to conduct educational discussions.

\section{PRIORITIES}

The group is provided with a set of discrete items - usually in the form of a list the components of which may not be distributed among participants - and at least one criterion. The pupils have to order these in a scale according to how far they conform, a young couple who have bought a tumbledown cottage may make a list of what needs are doing to it, in order of urgency; or a panel of judges may assess the relative merits of the contestants in a singing competition. These particular situations are difficult to be simulated in the classroom, but we can easily make up parallel problems which are appropriate for our classes.

The language having been used consists mostly of comparisons, and lower - level classes may benefit from a little practice in comparative and superlative constructions beforehand. In particular, the following words and phrases may be useful:

(c) Nabochuk Oleksandr

DOI (article): https://doi.org/10.32626/2227-6246.2021-51.165-189 
DOI: https://doi.org/10.32626/2227-6246.2021-51 2021. випУСК 51

more / less important than, the most / least important, more / less than, better / worse than, as good as, not so good as, I would rather..., I prefer..., That comes above / below / before / after... Which is better / more important?

The significant role in the achievement of the development of internal interference and conceptual correlation plays a controversy.

A dispute (from the Latin «Dispute» - to investigate, argue) is a public dispute according to a scientific or socially important topic. Disputes create optimal conditions for enriching pupils with educational information, preventing possible interpretations, teaching arguments, proving, defending their own opinions, criticizing their own minds and contributing to a climate of benevolence and respect for the opinions with others.

To develop the dialogical speech of pupils we use a definite methodological system that includes the principles of teaching oral communication, selection of subjects and linguistic material, its organization with the calculation of pupils' interests and opportunities, a set of exercises and forms of the activity, which determines a certain structure of the lessons of a foreign language.

Let us show the main methodological requirements, such as «communicative orientation». This is the guiding principle of learning a dialogue, as well as oral speech in general.

So, psychological requirements of facilitative interaction for the developing of teachers and pupils' creativity at the English lessons are:

a) the acquisition of a linguistically justifiable minimum of linguistic equipment that provides a level of communicative maturity;

b) an assessment of each linguistic creature in terms of the reality of its appearance in ordinary to act in the process of oral communication;

c) the formation of a situational or thematic minimum taking into account interests and future needs of pupils;

(c) Nabochuk Oleksandr

DOI (article): https://doi.org/10.32626/2227-6246.2021-51.165-189 
d) the communicative activity of speech operations when working with linguistic material;

e) the creation of a defined system of the activity, which is motivated by the need for linguistic communication.

The method of training dialogical speech should be specified, clearly selecting lexical and grammatical material. It is also necessary to take into account the age-specific features of pupils, to identify the motives and objects that interest them, which can be effective components of the communicative model of a real communication in the paradigm of educational settings.

Communicative orientations have two main forms of their implementation. The first is international communication. It is necessary that training is oriented on the need to communicate with native speakers. The second, very important form of communicative orientation is communication between compatriots in a foreign language (intranet communication is especially relevant at secondary school).

The instructor should select appropriate topics for dialogical communication, develop and specify it and offer pupils models of real situations that would satisfy their interests and stimulate dialogue. Such situations can arise both in the process of international and in the internal communication.

The training program should be based on the following series of typical communicative situations selected and processed in accordance with the principles of teaching dialogical communication and facilitative interaction as the types of communicative activity, with educational and didactic needs.

The problem is that in any dialogues pupils clearly knew their role having been skillfully improvised. To reach this the teacher needs a well thought out, clearly painted atlas - so called a situation report, situational and roles determined, a list of rational exercises for dialogical communication.

(c) Nabochuk Oleksandr

DOI (article): https://doi.org/10.32626/2227-6246.2021-51.165-189 


\section{Conclusions}

So, we conclude that facilitative interaction is characterized by the following suggestions. Firstly, creative activity is seen as a person's need to adapt to new conditions of the reality. It is the ability of the person to include something new into the process of his / her life, to adapt to external conditions of the activity, which, as a rule, promotes greater flexibility of the subject in solving problems and situations, increases the possibility of personal improvement and growth. Creative activity is seen as the process of inventing a product that did not yet exist for a given person (although this product may already exist in principles). The characteristics of these new products or processes are their novelty, originality, expediency, validity, the ability to meet their own needs, adequacy.

So, productive approach to the study of the development of creativity in the process of facilitative interaction shows that this approach to some extent reduces a person's creative ability to manifest his / her individual characteristics. The productive approach offers a very original and balanced understanding of the creativity, which is based on the universality of the creativity, its accessibility for everyone, the role of creativity not only as a way to adapt to external environmental conditions, but also as a tool for qualitative change.

\section{Literature}

Гончарук Наталія, Онуфрієва Ліана. Психологічний аналіз рівнів побудови комунікативних дій. Психолінгвістика. Психолингвистика. Psycholinguistics: Зб. наук. праць ДВНЗ «Переяслав-Хлельницький пед. ун-m ілені Григорія Сковороди». Переяслав-Хмельницький : ФОП Домбровська Я. М., 2018. Вип. 24 (1). С. 97-117. DOI 10.31470/2309-1797-2018-24-1-97-117.

Amabile, T. M., Conti, H., Lazenby, J., \& Herron, M. (1996). Assessing the work environment for creativity. Academy of Management Journal, 39, 1154-1184.

Amabile, T. M. (1983). The social psychology of creativity. New York : Springer-Verlag. 245 p.

(C) Nabochuk Oleksandr

DOI (article): https://doi.org/10.32626/2227-6246.2021-51.165-189 
Boden, M. A. (1991). The creative mind: myths and mechanisms. New York : Basic Books; London : Abacus. 171 p.

Bolle, R. (2014). Eignung für den Lehrerberuf? Leipziger Univ. Verl. 154 s. Collins, M. A., \& Amabile, T. M. (1999). Motivation and creativity. Handbook of Creativity, (pp. 297-313). R. Sternberg (Ed.). Cambridge.

Ekvall, G. (1997). Organizational conditions and levels of creativity. Creativity and innovation management, 6 (4), 195-205.

Ekvall, G., \& Britz, A. (2001). Perceptions of the best and worst climates for creativity: preliminary validation evidence for Situational Outlook Questionnaire. Creativity Research Journal, 13 (2), 171-184.

Enkvist, N. E. (1990). On the Interpretability of Texts in General, and Literary Texts in Particular. Literary Pragmatics. R. D. Sell (Ed.). New York - London : Longman. 363 p.

Flossdorf, B. (1981). Kreativität. Handbuch psychologischer Grundbegriffe, (ss. 572-579). In: G. Rexelius \& S. Grubitzsch (Hrsg.). Reinbek : Rowohlt.

Gehrmann, S. (2015). Bildungskonzepte und Lehrerbildung in europäischer Perspektive. Münster - New York : Waxmann. 206 s.

Jamison, K. R. (1995). Manic-depressive illness and creativity. Scientific American, 272, 62-67.

Kraus, K. (2015). Bildung von Lehrerinnen und Lehrern: Herausforderungen in Schule, Hochschule und Gesellschaft. Berlin - Toronto : Budrich UniPress. $145 \mathrm{~s}$.

Ludwig, A. M. (1992). Creative achievements and psychopathology: comparison among professions. Journal of Psychotherapy, 46, 330-356.

Mykhalchuk Nataliia, Ivashkevych Eduard. Psycholinguistic features of the development of social intelligence of the teacher. Психолінгвістика. Психолингвистика. Psycholinguistics: Зб. наук. праць ДВНЗ «Переяслав-Хлельницький пед. ун-т ілені Григорія Сковороди». Переяслав-Хмельницький : ФОП Домбровська Я. М., 2018. Вип. 23 (1). C. 242-257. DOI https://doi.org/10.5281/zenodo.1211618 (ISSN 2415-3397, Index Copernicus, Web of Science).

Mykhalchuk Nataliia, Kryshevych Olga. The peculiarities of the perception and understanding of Sonnets written by W. Shakespeare by the students of the Faculty of Foreign Languages. Психолінгвістика. Психолингвистика. Psycholinguistics: Зб. наук. праць ДВНЗ «Переяслав-Хлельницький пед. ун-т ілені Григорія Сковороди». Переяслав-Хмельницький : ФОП Домбровська Я. М., 2019. Вип. 26 (1). C. 265-285. DOI 10.31470/2309-1797-2019-26-1-265-285.

Renzulli, J. S. (1991). The National Research Center on the Gifted and Talented. Gifted Child Quarterly, 32 (2), 156.

(C) Nabochuk Oleksandr

DOI (article): https://doi.org/10.32626/2227-6246.2021-51.165-189 
DOI: https://doi.org/10.32626/2227-6246.2021-51 2021. випУСК 51

Zubiashvili, I., Kocharian, A., Lunov, V., Barinova, N., \& Onufriieva, L. (2020). Phenomenon of money: Social and psychological essence and functions. International Journal of Psychosocial Rehabilitation, 24 (3), 16291642. DOI 10.37200/IJPR/V24I3/PR200911. URL : https://www. scopus.com/record/display.uri?eid=2-s2.0-85080985552\&origin= resultslist $\&$ sort $=$ plf $-\mathrm{f} \& \mathrm{src}=\mathrm{s} \& \mathrm{sid}=\mathrm{b} 36 \mathrm{af} 771 \mathrm{df} 0576 \mathrm{~b} 1 \mathrm{~b} 8108 \mathrm{dc} 4$ de3433b4\&sot $=$ autdocs\&sdt $=$ autdocs $\& s l=18 \& s=A U-I D \% 285721460$ $1047 \% 29 \&$ relpos $=0 \&$ citeCnt $=0 \&$ search Term $=$.

\section{References}

Honcharuck, Nataliia, \& Onufriieva, Liana (2018). Psykholohichnyi analiz rivniv pobudovy komunikatyvnykh dii [Psychological analysis of levels of communicative actions' constructing]. Psykholinhvistyka. Psikholingvistika. Psycholinguistics - Psycholinguistics. Psycholinguistics. Psycholinguistics: Collection of Scientific Papers of Hryhorii Skovoroda University in Pereiaslav, 24 (1), 97-117. Pereiaslav-Khmelnytskyi : FOP Dombrovska Ya. M. DOI 10.31470/2309-1797-201824-1-97-117 [in Ukrainian].

Amabile, T. M., Conti, H., Lazenby, J., \& Herron, M. (1996). Assessing the work environment for creativity. Academy of Management Journal, 39, 1154-1184.

Amabile, T. M. (1983). The social psychology of creativity. New York : Springer-Verlag.

Boden, M. A. (1991). The creative mind: myths and mechanisms. New York : Basic Books; London : Abacus.

Bolle, R. (2014). Eignung für den Lehrerberuf? Leipziger Univ. Verl. [in German].

Collins, M. A., \& Amabile, T. M. (1999). Motivation and creativity. Handbook of Creativity, (pp. 297-313). R. Sternberg (Ed.). Cambridge.

Ekvall, G. (1997). Organizational conditions and levels of creativity. Creativity and innovation management, 6 (4), 195-205.

Ekvall, G., \& Britz, A. (2001). Perceptions of the best and worst climates for creativity: preliminary validation evidence for Situational Outlook Questionnaire. Creativity Research Journal, 13 (2), 171-184.

Enkvist, N. E. (1990). On the Interpretability of Texts in General, and Literary Texts in Particular. Literary Pragmatics. R. D. Sell (Ed.). New York - London : Longman.

Flossdorf, B. (1981). Kreativität. Handbuch psychologischer Grundbegriffe, (ss. 572-579). In: G. Rexelius \& S. Grubitzsch (Hrsg.). Reinbek : Rowohlt [in German].

(C) Nabochuk Oleksandr

DOI (article): https://doi.org/10.32626/2227-6246.2021-51.165-189 
Gehrmann, S. (2015). Bildungskonzepte und Lehrerbildung in europäischer Perspektive. Münster - New York : Waxmann [in German].

Jamison, K. R. (1995). Manic-depressive illness and creativity. Scientific American, 272, 62-67.

Kraus, K. (2015). Bildung von Lehrerinnen und Lehrern: Herausforderungen in Schule, Hochschule und Gesellschaft. Berlin - Toronto : Budrich UniPress [in German].

Ludwig, A. M. (1992). Creative achievements and psychopathology: comparison among professions. Journal of Psychotherapy, 46, 330-356.

Mykhalchuk, Nataliia, \& Ivashkevych, Eduard (2018). Psycholinguistic features of the development of social intelligence of the teacher. Psykholinhvistyka. Psikholingvistika. Psycholinguistics - Psycholinguistics. Psycholinguistics. Psycholinguistics: Collection of Scientific Papers of Hryhorii Skovoroda University in Pereiaslav, 23 (1), 242-257. Pereiaslav-Khmelnytskyi : FOP Dombrovska Ya. M. DOI https://doi.org/10.5281/zenodo.1211618 (ISSN 2415-3397, Index Copernicus, Web of Science).

Mykhalchuk, Nataliia, \& Kryshevych, Olga (2019). The peculiarities of the perception and understanding of Sonnets written by W. Shakespeare by the students of the Faculty of Foreign Languages. Psycholinguistics. Psykholinhvistyka. Psikholingvistika - Psycholinguistics. Psycholinguistics. Psycholinguistics: Collection of Scientific Papers of Hryhorii Skovoroda University in Pereiaslav, 26 (1), 265-285. Pereiaslav-Khmelnytskyi : FOP Dombrovska Ya. M. DOI 10.31470/ 2309-1797-2019-26-1-265-285.

Renzulli, J. S. (1991). The National Research Center on the Gifted and Talented. Gifted Child Quarterly, 32 (2), 156.

Zubiashvili, I., Kocharian, A., Lunov, V., Barinova, N., \& Onufriieva, L. (2020). Phenomenon of money: Social and psychological essence and functions. International Journal of Psychosocial Rehabilitation, 24 (3), 1629-1642. DOI 10.37200/IJPR/V24I3/PR200911. Retrieved from https://www.scopus.com/record/display.uri?eid= 2 -s2.0-85080985552\&origin $=$ resultslist\&sort $=$ plf-f\&src $=$ s\&sid $=$ b36af771df0576b1b8108dc4de3433b4\&sot=autdocs\&sdt=autdocs $\& \mathrm{sl}=18 \& \mathrm{~s}=\mathrm{AU}-\mathrm{ID} \% 2857214601047 \% 29 \&$ relpos $=0 \& \operatorname{citeCnt}=0 \&$ searchTerm $=$.

Набочук Олександр. Продуктивний підхід до проблеми фасилітативної інтеракції та розвитку творчості особистості

(c) Nabochuk Oleksandr

DOI (article): https://doi.org/10.32626/2227-6246.2021-51.165-189 


\section{АНОТАЦІЯ}

Мета статmі - висвітлити психологічні особливості продуктивного підходу до проблеми фрасилітативної інтеракції та розвитку творчості особистості.

Для розв'язання поставлених у роботі завдань використано такі теоретичні методи дослідження: категоріальний, структурно-функціональний, аналіз, систематизація, моделювання, узагальнення.

Результати дослідження. Теоретичний аналіз психологічних досліджень із порушеної проблеми дає підстави виокремити декілька основних підходів до вивчення творчості у зарубіжній психології: 1) психодинамічний підхід, що описує творчість через взаємовплив "Воно», "Я», "Над-Я»; 2) біхевіористичний підхід, який розглядає творчість як результат поведінки з чітким дотриманням схеми "стимул - реакція»; 3) прагматичний підхід, що наголошує на можливостях практичного використання людиною творчого продукту і, як наслідок, - виокремленні інших ресурсів творчого використання цього продукту; 4) психопатологічний підхід, що розглядає творчість як побічний продукт психічних розладів особистості; 5) продуктивний підхід, який оцінює творчість з огляду на новизну кінцевого продукту; 6) процесуальний підхід, що розглядає творчість як процес; 7) гуманістичний підхід, який робить акценти на власне самовираженні твория.

Доведено, що представники продуктивного підходу роблять акцент на креативності як вихідному продукті творчої діяльності. Творчими називаються не лише шедеври світової культури і мистецтва, винаходи в техніці, нові концепції в науці, але також й оригінальне оформлення інтер'єру приміщення, незвичний дизайн одягу тощо. Широкий діапазон креативних продуктів має актуалізувати здатність людини до їх диференціації відповідно до рівнів прояву творчості. Отже, представники продуктивного підходу вперше стверджують про рівневий характер творчої діяльності.

Висновки. Можемо зробити висновок про те, що для більшості досліджень фасилітативної інтеракції характерні такі положення. По-перше, творча діяльність розглядається як потреба людини пристосовуватися до нових умов дійсності. Це - здатність індивіда включати в процес свого життя дещо нове, адаптуватися до зовнішніх умов діяльності, що, як правило, сприяє більшій гнучкості суб'єкта у розв'язанні задач і проблем, підвищує можливість особистісного вдосконалення та зростання. (C) Nabochuk Oleksandr

DOI (article): https://doi.org/10.32626/2227-6246.2021-51.165-189 
DOI: https://doi.org/10.32626/2227-6246.2021-51 2021. випуск 51

Творча діяльність розглядається як прочес винайдення продукту, якого ще не існувало для даної людини (хоча чей продукт уже може існувати в принципі). Характеристиками цих нових продуктів чи процесів $є$ їх новизна, оригінальність, доцільність, валідність, здатність задовольняти власні потреби, адекватність.

Аналіз психологічних особливостей продуктивного підходу до вивчення творчості показує, що чей підхід тією чи іншою мірою редукує творчу здатність людини до прояву ії окремих характеристик. Продуктивний підхід пропонує досить оригінальне і збалансоване розуміння креативності, в основу якого покладено положення про універсальність творчості, їі доступність для кожного, про роль творчості не лише як способу адаптації людини до зовнішніх умов оточуючої дійсності, але й як інструменту їх якісних змін.

Ключові слова: продуктивний підхід, фасилітативна взаємодія, творчість людини, універсальність творчості, доступність творчості для кожного, адаптація особистості до зовнішніх умов навколишнього середовища.

Набочук Александр. Продуктивный подход к проблеме фасилитативного взаимодействия и развития творческой личности

\section{АННОТАЦИЯ}

Целью статьи является экспликация психологических особенностей продуктивного подхода к проблеме фрасилитативного взаимодействия и развития творческой личности.

Для решения поставленных в работе задач использованы следующие теоретические методы исследования: категориальный, структурно-функциональный, анализ, систематизация, моделирование, обобщение.

Результаты исследования. Теоретический анализ психологических исследований по данной проблеме позволил выделить несколько основных подходов к изучению творчества в зарубежной психологии: 1) психодинамический подход, который описывает творчество через взаимовлияния "Оно», "Я», "Сверх-Я»; 2) бихевиористский подход, рассматривающий творчество как результат поведения с четким соблюдением схемы "стимул - реакция»; 3) прагматический подход, который провозглашает возможности практического использования человеком творческого

(C) Nabochuk Oleksandr

DOI (article): https://doi.org/10.32626/2227-6246.2021-51.165-189 
продукта и, как результат, - выделение других ресурсов творческого использования данного продукта; 4) психопатологический подход, который рассматривает творчество как побочный продукт психических расстройств личности; 5) продуктивный подход, оченивающий творчество через новизну конечного продукта; 6) процессуальный подход - рассматривает творчество как прочесс, 7) гуманистический подход, который делает акценты собственно на самовыражении творца.

Доказано, что представители продуктивного подхода акцентируют внимание на креативности в исходном продукте творческой деятельности. Творческими называются не только шедевры мировой культуры и искусства, изобретения в технике, новые концепции в науке, но также и оригинальное оформление интерьера помещения, необычный дизайн одежды и др. Широкий диапазон креативных продуктов способен актуализировать способность человека к их дирфреренциации в соответствии с уровнями проявления творчества. Таким образом, представители продуктивного подхода впервые заявляют касательно уровневого характера творческой деятельности.

Выводы. Можем сделать вывод о том, что для большинства исследований фасилитативного взаимодействия являются характерными следующие положения. Во-первых, творческая деятельность рассматривается как потребность человека приспосабливаться к новым условиям действительности. Это - способность индивида включать в прочесс своей жизни нечто новое, адаптироваться к внешним условиям деятельности, что, как правило, способствует большей гибкости субъекта в решении задач и проблем, повышает возможность личностного совершенствования и роста. Творческая деятельность рассматривается как процесс изобретения продукта, которого еще до тех пор не существовало для данного человека (хотя этот продукт уже может существовать в принципе). Характеристиками этих новых продуктов или процессов являются их новизна, оригинальность, челесообразность, валидность, способность удовлетворять собственные потребности, адекватность.

Анализ психологических особенностей продуктивного подхода к изучению творчества показывает, что этот подход в той или иной мере редуцирует творческую способность человека к проявлению ее отдельных характеристик. Продуктивный подход предлагает достаточно оригинальное и сбалансированное понимание креативности, в основе (c) Nabochuk Oleksandr

DOI (article): https://doi.org/10.32626/2227-6246.2021-51.165-189 
ISSN 2227-6246 (Print)

DOI: https://doi.org/10.32626/2227-6246.2021-51

2021. ВИПУСК 51

которого находится положение касательно универсальности творчества, его доступности для каждого, роли творчества не только как способа адаптации человека к внешним условиям окружающей действительности, но и как инструмента ее качественных изменений.

Ключевые слова: продуктивный подход, фрасилитативное взаимодействие, творчество личности, универсальность творчества, доступность творчества для каждого, адаптация личности к внешним условиям окружающей среды.

Original manuscript received January 12, 2021 Revised manuscript accepted February 17, 2021 